\title{
First occurrence of Pictetia (Ammonoidea) from the Albian of Japan and its systematical implications
}

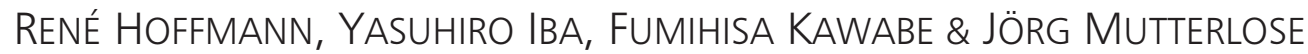

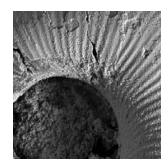

\begin{abstract}
Here, we describe for the first time the occurrence of well preserved Pictetia from the Albian of northeastern Japan (Miyako Group) and discuss the implications for the systematic assignment of the genus. A detailed systematic description of $P$. astieriana based on the newly collected material is given. Earlier systematic assignment to lytoceratids resulted from similar conch morphology and ornamentation. Based on the new knowledge of the development of the juvenile suture lines, Pictetia is tentatively assigned to the Hamitidae. - Key words: systematics, Ancyloceratina, Hamitidae, Pictetia, Cretaceous, Northwest Pacific, Miyako Group, Japan.
\end{abstract}

Hoffmann, R., IbA, Y., KaWAbe, F. \& Mutterlose, J. 2013. First occurrence of Pictetia (Ammonoidea) from the Albian of Japan and its systematical implications. Bulletin of Geosciences 88(3), 517-524 (5 figures). Czech Geological Survey, Prague. ISSN 1214-1119. Manuscript received August 17, 2012; accepted in revised form February 11, 2013; published online April 5, 2013; issued July 3, 2013.

René Hoffmann (corresponding author) \& Jörg Mutterlose, Institut für Geologie, Mineralogie und Geophysik, Ruhr-Universität Bochum, 44801, Germany; Rene.Hoffmann@rub.de・Yasuhiro Iba, Department of Natural History Sciences, Hokkaido University, Sapporo, 060-0810, Japan • Fumihisa Kawabe, Ministry of Education, Culture, Sports, Science and Technology, Tokyo 100-8959, Japan

For ammonoids with an uncoiled conch, Wiedmann (1966) introduced the taxon Ancyloceratina. This group originated in the Late Jurassic (Early Tithonian) and had a remarkable taxonomic and morphological diversification in the world's oceans during the Cretaceous (Cecca 1997, 1998). The systematics of the higher taxa of the Ancyloceratina is based on the primary suture line and not on conch shape or ornamentation. Besides the primary suture line, the adult body chamber, one of the diagnostic features for genus determination, was unknown from Pictetia. Therefore, any further systematic assessment of Pictetia was impossible. Nevertheless, it turned out that Pictetia lacks any diagnostic lytoceratid characters such as the septal lobe, a character that constitutes the monophyly of Lytoceratoidea, and was therefore excluded from this taxon (Hoffmann et al. 2009, Hoffmann 2010). Earlier systematic assignment to lytoceratids resulted from the similar conch morphology and ornamentation.

Newly collected specimens of Pictetia astieriana from the Lower Albian of the Miyako Group (NW Japan) represent the first reliable report of Pictetia from the Cretaceous of the Northwest Pacific. This new material is well preserved including the juvenile part of the shell and allows a detailed description. This sheds new light on the higher systematic assignment of Pictetia.

\section{Geological setting}

The Miyako Group in the Rikuchu area in Northeast Japan (Fig. 1) is an Upper Aptian-Lower Albian siliciclastic sequence with abundant shallow-marine fossils such as rudists and orbitolinids (Hanai et al. 1968, Sano 1991, Iba \& Sano 2007). This group is subdivided in four formations: Raga, Tanohata, Hiraiga and Aketo formations in ascending order (Hanai et al. 1968). Late Aptian ammonites such as Nolaniceras yaegashii, Hypacanthoplites subcornuerianus and Eodouvilleiceras matsumotoi have been recovered from the Tanohata Formation and the lower part of the Hiraiga Formation (e.g., Obata 1969, Obata \& Futakami 1992). Based on the ammonite fauna described by Obata (1969) and Obata \& Futakami (1992) including Douvilleiceras mammillatum, the upper part of the Hiraiga Formation and the Aketo Formation belong to the Lower Albian. Specimens referable to Pictetia have been collected from the float, probably originating from the Aketo Formation (Fig. 1).

\section{Systematic palaeontology}

Morphological terms in the systematic description are those used in the Treatise on Invertebrate Paleontology 


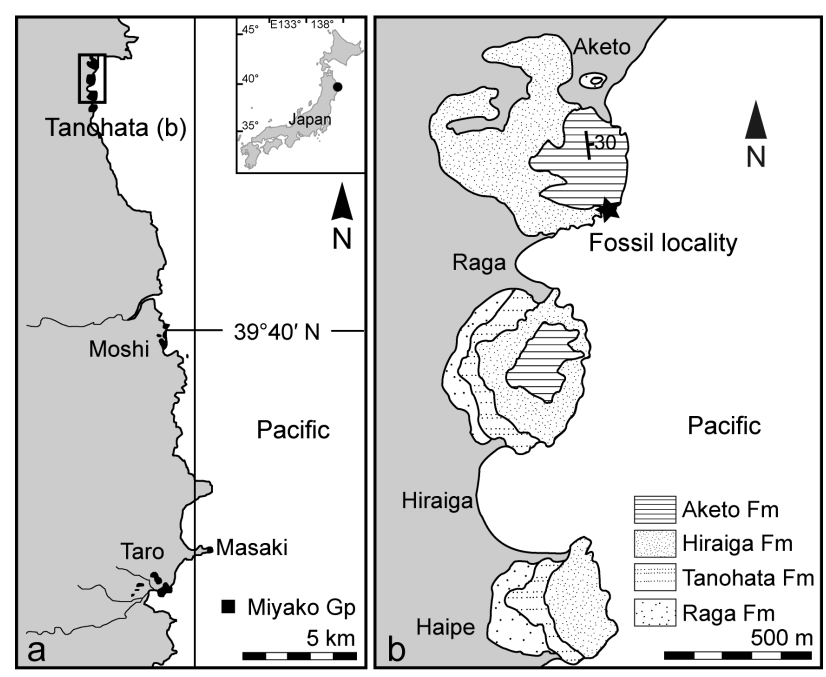

Figure 1. Locality map of Pictetia astieriana in the Rikuchu area, Northeast Japan. Pictetia astieriana specimens have been collected from the float, probably originating from the Aketo Formation. Geological map based on Fujino et al. (2006).

(Arkell et al. 1957). Quantifiers used to describe the shape of ammonoid conch replicate those proposed by Matsumoto (1954, p. 246). We apply the suture line terminology of Wedekind (1916) with E (external lobe), A (adventive lobe), L (lateral lobe), U (umbilical lobe) and I (internal lobe); see also Kullmann \& Wiedmann (1970) and Korn et al. (2003). For the characterization of ontogenetic changes of the conch morphology, we follow Korn (2010). For the morphological description, we use the following abbreviations: $\mathrm{dm}=$ diameter, $\mathrm{uw}=$ umbilical width, $\mathrm{wh}=$ whorl height, $\mathrm{ww}=$ whorl width, $\mathrm{CWI}=\mathrm{ww} / \mathrm{dm}, \mathrm{WWI}=\mathrm{ww} / \mathrm{wh}$, $\mathrm{UWI}=\mathrm{uw} / \mathrm{dm}, \mathrm{WER}=$ whorl expansion rate.

\section{Suborder Ancyloceratina Wiedmann, 1966}

Undoubtedly, the Ancyloceratina represent a heterogeneous group containing ammonites with a quadri- or quinquelobate primary suture (Wright et al. 1996) as well as taxa with anaptychi and aptychi (Engeser \& Keupp 2002). Therefore, it is generally accepted that the Ancyloceratina sensu Wiedmann (1966) represent a polyphylum (Doguzhaeva \& Mikhailova 1982, Engeser \& Keupp 2002, Hoffmann et al. 2009).

Suborder Ancyloceratina Wiedmann, 1966

Superfamily Turrilitaceae Gill, 1871

Family Hamitidae Gill, 1871

\section{Genus Pictetia Uhlig, 1883}

Type species. - Crioceras astierianus d'Orbigny, 1842, p. 468 , pl. $115^{\text {bis }}$, figs $3-5$; by subsequent designation of Spath (1923, p. 21).
Remarks. - The diagnosis given by Wright et al. (1996) is very short and insufficient. However, a more comprehensive diagnosis was presented by Casey (1960, p. 3). The genus was discussed in detail by Hoffmann et al. (2009). Unfortunately, most of the diagnostic features like the morphology of the adult body chamber or the course of the primary suture line were unknown. Nevertheless, Bert (2012) proposed the monogeneric subfamily Pictetinae and, based on conch morphology and suture line, tentatively put his new taxon within the Macroscaphitidae.

Due to the observed early juvenile suture line development, we tentatively assign Pictetia to the Hamitidae and reject both ideas introduced by Bert (2012). A new subfamily is not necessary and as we will show below, the Macroscaphitidae are not the closest relatives of Pictetia.

Occurrence. - Pictetia astieriana occurs in the Lower Albian of Japan (Miyako Group, Aketo Formation, reported herein) and of Tunisia (mammillatum zone, radenaci zone $=$ middle part of the mammillatum zone; Chihaoui et al. 2010, Latil 2011).

Pictetia astieriana was reported from the middle Albian of England (dentatus zone; Spath 1923), France (lectotype from the dentatus zone; Kennedy 2006), California (packardi zone associated with Cleoniceras; Rodda \& Murphy 1992), Austria (Vorarlberg, dentatus zone; Föllmi 1989), Madagascar (inaequinodum zone; Collignon 1949, 1963; Hoffmann et al. 2009), and Bulgaria (dentatus zone; Ivanov 1993).

Pictetia depressa was found in the Lower Albian of England (mammillatum zone; Casey 1960, 1980), Bulgaria (tardefurcata zone; Ivanov 1993), and a single $P$. aff. depressa comes from South Africa (mammillatum zone, Mzinene Formation Albian II-III; Kennedy \& Klinger 1978). The lectotype of P. depressa (Fig. 4) was reported from the Gault inférieur of Switzerland (Sainte-Croix) by Pictet \& Campiche (186, p. 29, pl. XLV, figs 3a-d). According to Renz (1968, pp. 8, 9) it seems likely that the lectotype of $P$. depressa was found in the Lower Albian mammillatum zone. Pictetia sp. was discovered in the Lower Albian (mammillatum zone) of California by Rodda \& Murphy (1992) and from northeast Germany (pers. comm. J. Lehmann). Occurrences of $P$. astieriana in the Upper Aptian (e.g. Sinzow 1905 , p. 323 for Mangyshlak) are neither figured nor are stratigraphic details known. Therefore, we regard the distribution of the genus as restricted to the Early and Middle Albian.

The Pacific was the largest ocean during the Cretaceous and therefore plays a key role for the understanding of ammonite biogeography on a global scale. This is the first reliable report of Pictetia from the Northwest Pacific (Fig. 5). Pictetia co-occurred with mesogean taxa (e.g. rudist and orbitolinids; Masse 1992) indicating the Cretaceous tropical marine environment and biotic realm. 
René Hoffmann et al. • Pictetia (Ammonoidea) from the Albian of Japan and its systematical implications
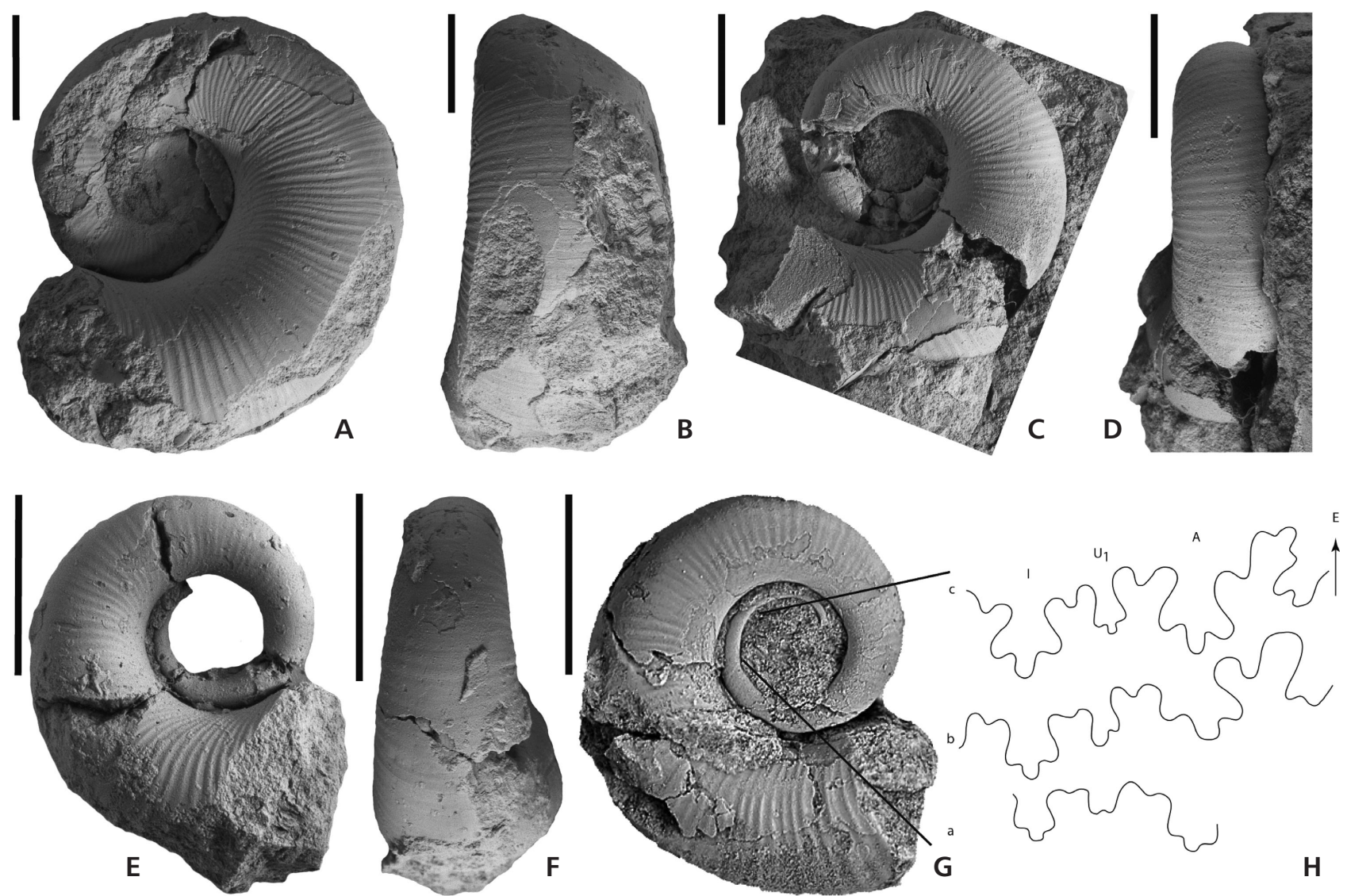

Figure 2. Pictetia astieriana from Japan (Miyako Group). A, B - IPMM 62956, C, D - IPMM 62959, E, F - IPMM 62951, G - IPMM 62960, most complete specimen with the juvenile part of the conch preserved with a low WER, $\mathrm{H}$ - suture line drawings after complete extraction of the juvenile conch of P. astieriana (specimen G) with a) at Wh $0.8 \mathrm{~mm}, \mathrm{~b}$ ) at $\mathrm{Wh} 1.0 \mathrm{~mm}, \mathrm{c}$ ) at Wh $1.1 \mathrm{~mm}$ showing a quadrilobate suture with trifid $\mathrm{I}, \mathrm{U}_{1}$ and $\mathrm{A}$ lobe, a broad E and bifid saddles; scale bar $=10 \mathrm{~mm}$.
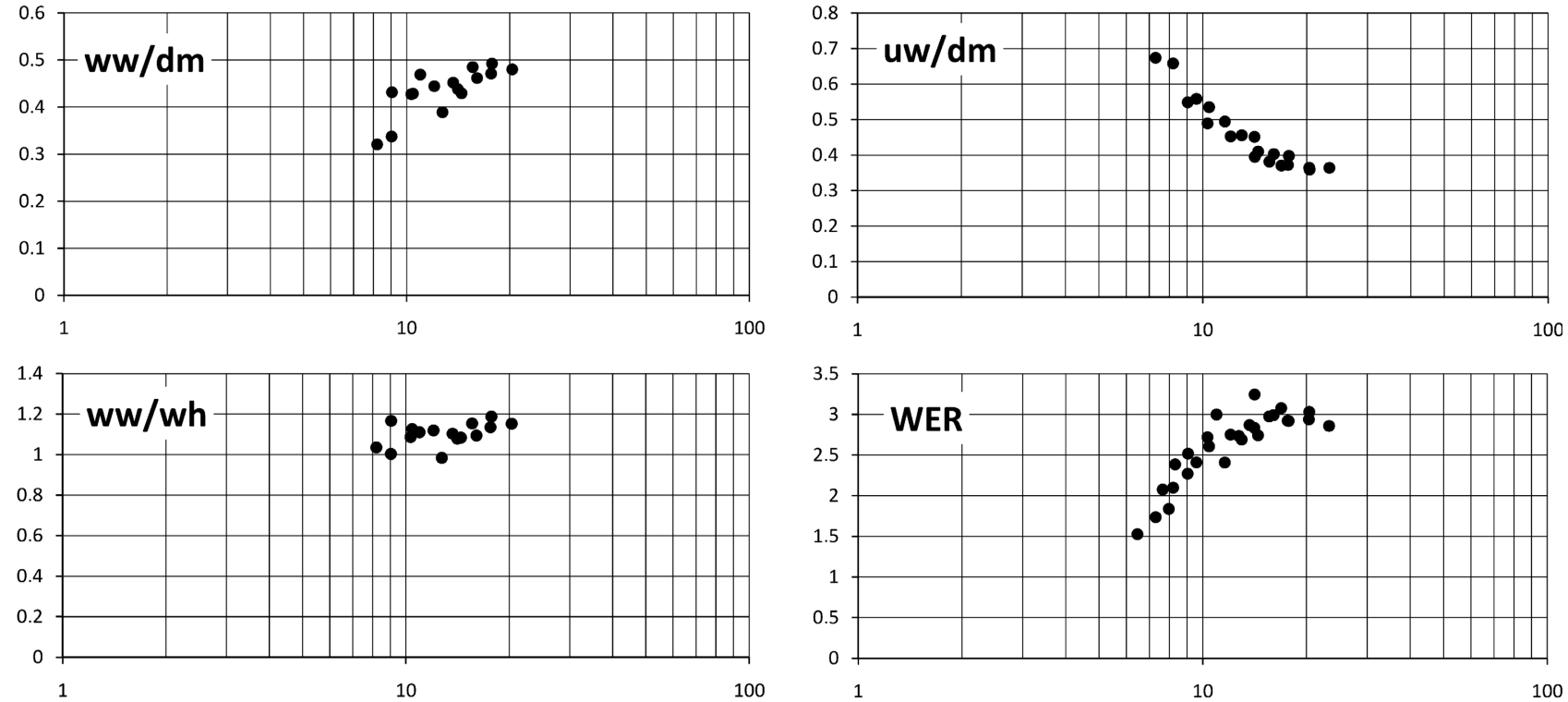

Figure 3. Ontogenetic development of conch parameters for Pictetia astieriana from Japan (Miyako Group) including all available specimens, top left: CWI, top right: UWI, bottom left: WWI, bottom right: WER against the diameter (mm). 
Pictetia was found from the Aketo Formation that contains abundant orbitolinids. These lines of evidence indicate that Pictetia was dwelling in warm water conditions.

\section{Pictetia astieriana d'Orbigny, 1842}

Material. - IPMM 62949-62975, 63272-63273 (IPM: Iwate Prefectural Museum, Japan), a total number of 29 specimens from the Miyako Group were studied. For synonymy see Hoffmann et al. (2009).

Description. - The shell is very small to fairly small and varies between 14-39 mm in diameter with criocone coiling throughout ontogeny. The whorl section is circular to subcircular depressed without an umbilical shoulder. Juvenile parts of the shell show a low whorl height expansion. The best-preserved specimen (IPMM 62960; Fig. 2G) retains its juvenile conch. The lowest recorded whorl height is $0.4 \mathrm{~mm}$, reaching $1.2 \mathrm{~mm}$ after $180^{\circ}$ and $3.5 \mathrm{~mm}$ after completion of one whorl. Also, the more or less pronounced dorsal impression is present. For the ontogenetic trajectories of WER, WWI, UWI, and CWI see Fig. 3. The umbilicus is moderately wide. The convex flanks converge to a broad rounded venter. Ornamentation consists of fine, irregularly spaced ribs of similar magnitude crossing the venter without weakening. Ribs starting at the dorsal area are strongly rursiradiate. They become radial at about mid-flank and cross the venter in a slightly projected direction. From about 30 ribs per $1 / 4$ whorl, some ribs are bifurcated on the lower flank. A weak strigation on the shell surface is only visible in sided light. The juvenile suture line is visible only in a single specimen (Fig. $2 \mathrm{H}$ ). At $\mathrm{wh}=0.8 \mathrm{~mm}$, this specimen shows a quadrilobate suture line with a trifid I, a bifid $\mathrm{U}_{1}$ and a broad trifid A. Following Schindewolf (1961), the small impression in the saddle I/U is regarded as incision and not as a lobe (Fig. 2Ha). Saddles are bifid throughout ontogeny with decreasing length from external to internal side. The suture line shows the tendency of trifid lobes and bifid saddles (Fig. $2 \mathrm{Hb}$ ). The base of $\mathrm{U}_{1}$ is slender and shorter than I, becoming asymmetric in shape. The base of A is broad, trifid and of similar depth like I and deeper than E. At wh $=1.25 \mathrm{~mm}$, all lobes are trifid. A-lobe is asymmetric bifid and the saddle E/A becomes increasingly complex (Fig. 2Hc). The body chamber is not preserved.

Remarks. - Following the revision by Hoffmann et al. (2009), the Japanese material, which is characterized by a circular whorl cross-section and a weak dorsal depression, represents $P$. astieriana. The best-preserved specimen is about $23 \mathrm{~mm}$ in diameter and has its earliest whorls with a wh $=0.4 \mathrm{~mm}$ preserved (Fig. 2Ha). It is therefore adopted that only a small portion of the whorl is missing and Pictetia has a postembryonic umbilical opening of about $4.5 \mathrm{~mm}$ in diameter. For comparison of the new findings, we figure (Fig. 4) here the lectotype of $P$. depressa (Pictet \& Campiche, 1861) designated by Casey (1960, p. 4) from Perte du Rhône and housed at the natural history museum of Genève (Switzerland). Records of Pictetia from Japan were listed by Obata (1967, p. 67, 1969, p. 173, 1973, p. 312) as Pictetia sp. for the Aketo Formation but neither described nor figured. Since it was never indicated where Obata's material was stored, its actual location remains unclear [pers. comm. S. Toshimitsu (Tsukuba) 2008]. A fragmented lytoceratid ammonite, later assigned to ?Pictetia by Matsumoto (1980), was reported by Katto \& Obata (1975) from the Lower Cretaceous (Upper Aptian-Middle Albian) Shimantogawa Group of the Shimanto Belt of Shikoku, southwest Japan. The assignment of that specimen to Pictetia was refuted by Hoffmann et al. (2009). Nevertheless, Toshimitsu \& Hirano (2000) used these records for the database of Cretaceous ammonoids in Japan.

Age. - Early Albian of Japan (Miyako Group, Aketo Formation).

\section{Discussion}

The material from Japan can be assigned to Pictetia astieriana unequivocally. For the first time, a specimen revealed details of the earliest sutural ontogeny of Pictetia. A quadrilobate suture line was reported by d'Orbigny (1840-1842), Pictet \& Campiche (1861-1864), Casey (1960) and Schindewolf (1961, p. 45/679). These documentations of a quadrilobate juvenile suture line ( $w h=$ $0.8 \mathrm{~mm}$, Fig. $2 \mathrm{Hb}$ ) led us to the assumption that Pictetia retains four lobes (EAUI) throughout ontogeny.

The exclusion of Pictetia from the Lytoceratoidea and the assignment to the Ancyloceratina is now substantiated by the knowledge of the early juvenile suture line development and is in agreement with Hyatt (1900), Schindewolf (1961), Hoffmann et al. (2009), and Hoffmann (2010) but in contrast to the assignment presented by Wright et al. (1996). Owing to the trifid I, $\mathrm{U}_{1}$ and A (Fig. 2Hb) and the lack of a septal lobe, a character that constitutes the monophylum Lytoceratoidea, besides loose coiling supports the exclusion of Pictetia from the Lytoceratoidea. All morphological similarities between Pictetia and the Lytoceratoidea (ornamentation, constrictions, coiling and whorl shape) are regarded as plesiomorphic or homoplastic characters apparently unsuitable for higher systematic assignment (Hoffmann et al. 2009).

Since the major contributions to ammonoid systematics by Arkell et al. (1957), Schindewolf (1961-1968) and Wiedmann (1966), it is widely accepted that the superfamily Ancylocerataceae was derived from the lytoceratid stock and subsequently, the Turrilitaceae was derived from 

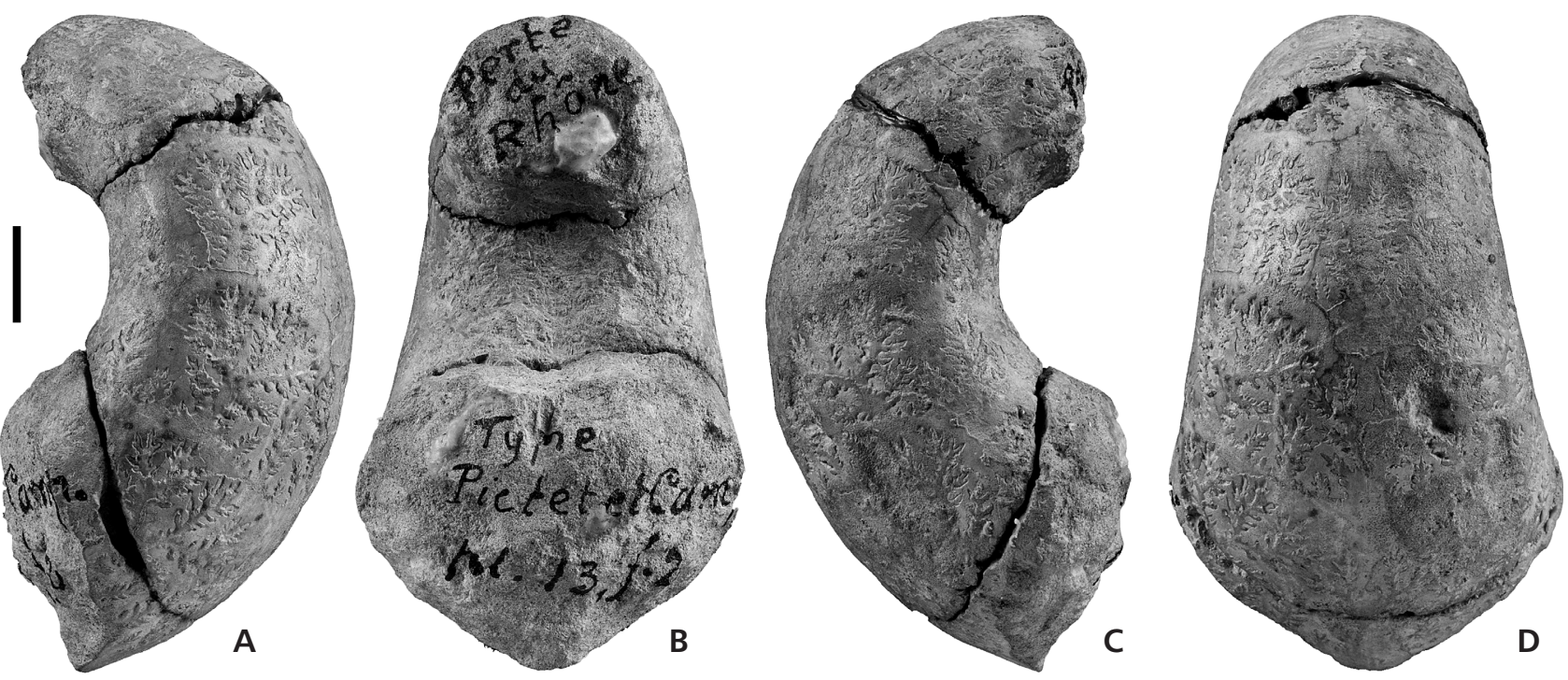

Figure 4. A-D - lectotype of Pictetia depressa from the lower Albian of Perte du Rhône, subsequent designated by Casey (1960), original of Pictet \& Campiche (1861, pl. 45, figs 3a-d); A - lateral view, B - ventral view, C - dorsal view, D - lateral view. Housed at the Musuem of Natural History in Genčve (coll. No.: AIV-96-17544).
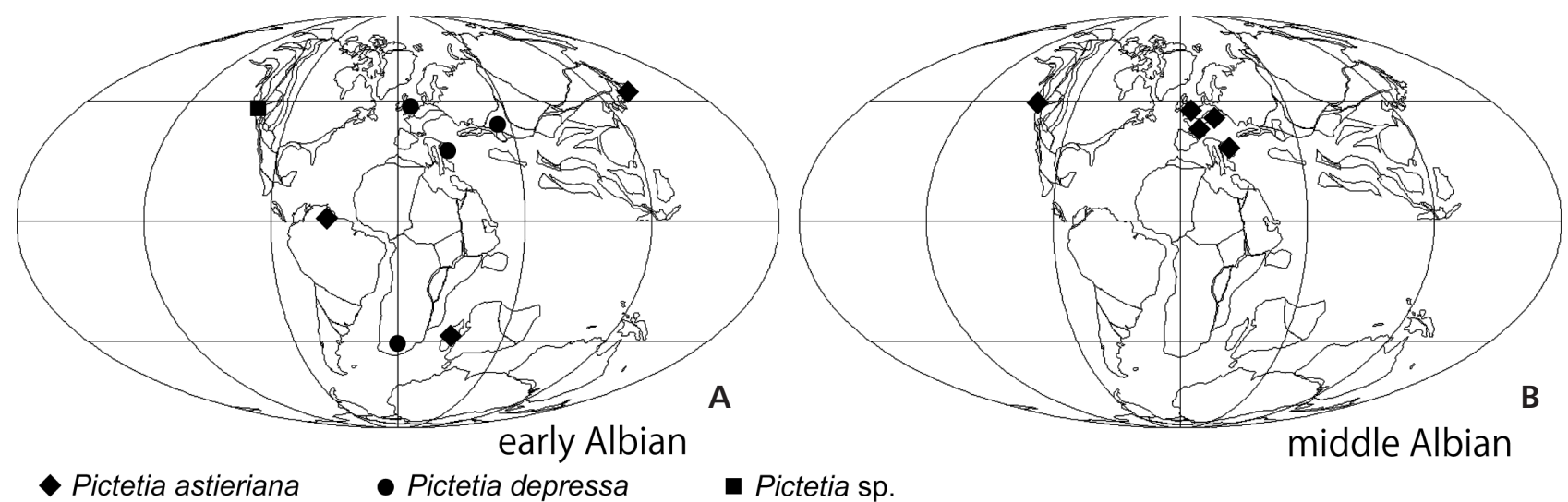

Figure 5. Distribution of Pictetia astieriana and P. depressa during the early to middle Albian. A - early Albian (110 Ma), B - middle Albian (100 Ma). Paleomap based on Eldridge et al. (2000).

the former group. That idea is mainly based on the suture line development concerning the low number of elements becoming more or less strongly slit during ontogeny. Nevertheless, both the Ancylocerataceae, with predominantly trifid lobes, and the Ancyloceratina are recognized as a paraphylum (Szives \& Monks 2002).

The number of lobes, four or five, is unstable in the Ancylocerataceae during ontogeny, while only four lobes occur in the Turrilitaceae. Due to the fact that not a single genus of Jurassic and Cretaceous Lytoceratoidea (Hoffmann 2010) displays a quadrilobate suture during ontogeny, the hypothesis of direct derivation of the Turrilitaceae from the lytoceratid stock (Doguzhaeva \& Mikhailova 1982) is rejected. Comparing the superfamilies Ancylocerataceae and Turrilitaceae with the diagnostic features now known for Pictetia (four lobes throughout ontogeny), it appears reasonable to place the genus within the Turrilitaceae with predominantly bifid lobes.

The oldest representative of the superfamily Turrilitaceae is the family Anisoceratidae ?Upper Aptian-Lower Albian (Wright et al. 1996). Most of the younger members of the Anisoceratidae show bifid lobes but trifid lobes occur in the older members. A similar suture line configuration with trifid lobes is present in the closely related Lower Albian paraphyletic Hamitidae (Monks 1999, Monks 2002, Szives \& Monks 2002). Based on the ontogenetic changes from juvenile trifid lobes to later ontogenetic stages with subsymmetric bifid lobes, Pictetia obviously belongs to one of these two groups. The striking similarities between Pictetia and these two families might be the reason for re-identification of two species formerly referred to as Pictetia (P. arcuata and P. crassecostata) but 
later assigned to Ephamulina, a genus belonging to the Anisoceratidae (Collignon 1963, Kennedy et al. 2000, Szives \& Monks 2002, Szives et al. 2007).

Based on the presence or absence of ventrolateral and/ or lateral tubercles, members of the Anisoceratidae are distinguished from the Hamitidae. Due to the lack of tubercles in Pictetia, it appears appropriate to assign the genus to the Hamitidae. That viewpoint is substantiated by the presence of 5-6 varices per whorl (constrictions visible on the internal mould) and the asymmetric suture line (Schindewolf 1961, Hoffmann et al. 2009) in Pictetia, both are non-typical for Anisoceratidae.

Furthermore, representatives of the Hamitidae are characterized by a circular to compressed whorl section and annular ribs, all features present in Pictetia. Both members of the Hamitidae such as Hamites or Lytohamites and Pictetia share a similar suture line compared to their complexity and particular development with a trifid I lobe, bifid saddles, subsymmetric bifid lobes and a similar median siphonsal saddle of the E lobe.

\section{Conclusions}

New material of from Japan revealed poorly known and unknown details of the early suture lines and suture ontogeny. In combination with other morphological details, this allows us to conclude that Pictetia, with its first occurrence in the Lower Albian, represents one of the oldest members of the Hamitidae.

\section{Acknowledgements}

We thank K. Komori (Ninohe-gun) and M. Oishi (Morioka) for giving us the opportunity to study their fossil collection. Thanks are extended to N. Monks (London) and C. Klug (Zurich) for fruitful discussions. We are also grateful to C. Meister (Geneva) for providing us the photographs of the lectotype of $P$. depressa and to S. Toshimitsu (Tsukuba) for sharing his knowledge about Japanese Pictetia. This research was financially supported by a DFG grant (Ke 322/32-1 for R.H.) and JSPS Grant-in-Aid for Scientific Research (No. 23916011 for F.K., No. 23840002 for Y.I). The two reviewers J. Lehmann (Bremen) and Y. Shigeta (Tokyo) substantially improved an earlier draft of the manuscript. We are also grateful to J. Klein (Vinkeveen) for supporting us with rare literature and G. Schreiber (Münster) for the technical preparation.

\section{References}

Arkell, W.J., Furnish, W.M., Kummel, B., Miller, A.K., Moore, R.C., Schindewolf, O.H., Sylvester-Brady, P.C. \& Wright, C.W. 1957. Part L. Mollusca 4. Cephalopoda. Ammonoidea. In Moore, R.C. (ed.) Treatise on invertebrate pale- ontology. L490 pp. The Geological Society of America \& The University of Kansas Press, Lawrence.

Bert, D. 2012. Les ammonites du Niveau Paquier (Albien basal, Crétacé inférieur) du Sud-Est de la France. Fossiles 12, 6-27.

Casey, R. 1960. A monograph of the Ammonoidea of the Lower Greensand, Part 1. Palaeontographical Society Monographs 490, 1-44.

Casey, R. 1980. A monograph of the Ammonoidea of the Lower Greensand, Part 9. Palaeontographical Society Monographs 557, 633-660.

CeCCA, F. 1997. Late Jurassic and early Cretaceous uncoiled ammonites; trophism-related evolutionary processes. Comptes Rendus de l'Académie des Sciences, Series IIA, Earth and Planetary Science 325, 629-634.

CECCA, F. 1998. Ipotesi sul ruolo del trofismo nell'evoluzione di ammoniti con conchiglie svolte: le radiazioni adattative delle Ancyloceratina (Ammonoidea) alla fine del Giurassico e nel Cretaceo inferior. Rendiconti Science Fisiche e Naturali Lincei 9(9), 213-226.

DOI 10.1007/BF02904405

Chinaoui, A., Jaillard, E., Latil, J.-L., Zghal, I., Susperregui, A.-S., Touir, J. \& Ouali, J. 2010. Stratigraphy of the Hameima and lower Fahdene Formations in the Tadjerouine area (Northern Tunisia). Journal of African Earth Sciences 58, 387-399.

DOI 10.1016/j.jafrearsci.2010.02.008

Collignon, M. 1949. Recherches sur les faunes Albiennes de Madagascar. I. L'Albien d'Ambarimaninga (Madagascar). Annales Géologiques Service des Mines de Madagascar 16, $1-128$.

Collignon, M. 1963. Atlas des fossiles characteristiques de Madagascar - Fascicule 10 (Albien). Service Géologique Tananarive 1963, 1-185.

Doguzhaeva, L. \& Mikhailova, I.A. 1982. The genus Luppovia and the phylogeny of Cretaceous heteromorphic ammonoids. Lethaia 15, 55-65.

DOI 10.1111/j.1502-3931.1982.tb01120.x

EldRIDGE, J.D., WALSh, D. \& SCOTESE, C.R. 2000. Plate Tracker for Windows/NT, Version 2.0. Palaeomap Project, Arlington, Texas.

Engeser, T. \& Keupp, H. 2002. Phylogeny of the aptychi-possessing Neoammonoidea (Aptychophora nov., Cephalopoda). Lethaia 34, 79-96.

DOI 10.1080/002411602317345894

FölLMI, K.B. 1989. Beschreibung neugefundener Ammonoidea aus der Vorarlberger Garschella-Formation (Aptian-Albian). Jahrbuch der Geologischen Bundesanstalt, Wien 132, 105-189.

Fujino, S., Masuda, F., Tagomori, S. \& Matsumoto, D. 2006. Structure and depositional processes of a gravelly tsunami deposit in a shallow marine setting: Lower Cretaceous Miyako Group, Japan. Sedimentary Geology 187, 127-138. DOI 10.1016/j.sedgeo.2005.12.021

Hanai, T., OBAta, I. \& Hayami, I. 1968. Notes on the Cretaceous Miyako Group. Memoirs of the National Science Museum 1, 20-28. [in Japanese with English abstract] 
Hoffmann, R. 2010. New insights on the phylogeny of the Lytoceratoidea (Ammonitina) from the septal lobe and its functional interpretation. Revue de Paléobiologie 29, 1-156.

Hoffmann, R., Keupp, H. \& Wiese, F. 2009. The systematic position of the Lower Cretaceous heteromorphic ammonite Pictetia Uhlig, 1883. Paläontologische Zeitschrift 83, 521-531.

DOI 10.1007/s12542-009-0036-2

Hyatт, A. 1900. Cephalopoda, 502-604. In Eastman, C.R. (ed.) Textbook of Paleontology (adapted from German, authored by Karl A. von Zittel), $1^{\text {st }}$ English Edition. Macmillan and Co., London \& New York.

Iвa, Y. \& SANo, S. 2007. Mid-Cretaceous step-wise demise of the carbonate platformbiota in the Northwest Pacific and establishment of the North Pacific biotic province. Palaeogeography, Palaeoclimatology, Palaeoecology 245, 462-482. DOI 10.1016/j.palaeo.2006.09.008

Ivanov, M. 1993. Albian representative of Lytoceratina Hyatt, 1889 in northwestern Bulgaria. Geologica Balcanica 23, 45-64.

Katтo, J. \& OватA, I. 1975. Note on an ammonite from the Shimanto Belt of Shikoku. Memoirs of the National Science Museum 8, 27-31.

KenNedy, W.J. 2006. Pictetia astieriana, 139. In Fischer, J.-C. \& Gauthier, H. (eds) Révision critique de la Paléontologie Française d'Alcide d'Orbigny. Vol. IV. Céphalopodes Crétacés. Backhuys Publishers, Leiden.

Kennedy, W.J., Gale, A.S., Bown, P.R., Caron, M., Davey, R.J., GRÖCKE, D. \& WRAY, D.S. 2000. Integrated stratigraphy across the Aptian-Albian boundary in the Marnes Bleues, at the Col de Pré Guittard, Arnayon (Drome), and at Tartonne (Alpes de Haute Provence), France: a candidate Global Boundary Stratotype Section and Boundary Point for the base of the Albian stage. Cretaceous Research 21, 591-720. DOI 10.1006/cres.2000.0223

Kennedy, W.J. \& Klinger, H.C. 1978. Cretaceous faunas from Zululand and Natal, South Africa. The ammonite family Lytoceratidae Neumayr, 1875. Annals of the South African Museum 74, 257-333.

Korn, D. 2010. A key for the description of Palaeozoic ammonoids. Fossil Record 13, 5-12.

DOI 10.1002/mmng.200900008

Korn, D., Ebbighausen, V., Bockwinkel, J. \& Klug, C. 2003. The A-mode sutural ontogeny in prolecanitid ammonoids. Palaeontology 46, 1123-1132. DOI 10.1046/j.0031-0239.2003.00336.x

Kullmann, J. \& Wiedmann, J. 1970. Significance of sutures in phylogeny of ammonoidea. The University of Kansas Paleontological Contributions 47, 1-32.

LatIL, J.-L. 2011. Early Albian ammonites from Central Tunisia and adjacent areas of Algeria. Revue de Paléobiologie 30, 321-429.

Löser, H., Sugiyama, T. \& Mori, K. 2002. Catalogue of the Mesozoic corals of Japan. Bulletin of the Tohoku University Museum 2, 1-46.

Masse, J.-P. 1992. The Lower Cretaceous Mesogean benthic eco- systems: palaeoecologic aspects and palaeobiogeographic implications. Palaeogeography, Palaeoclimatology, Palaeoecology 91, 331-345.

DOI 10.1016/0031-0182(92)90075-G

Matsumoto, T. 1954. The Cretaceous System in the Japanese Islands. 324 pp. Japan Society for the Promotion of Science, Tokyo.

Matsumoto, T. 1980. Cephalopods from the Shimanto belt of Kochi Prefecture (Shikoku), 283-298. In TAIRA, A. \& TASHIRo, M. (eds) Geology and Paleontology of the Shimanto Belt. Rinyakosaikai Press, Kochi.

Monks, N. 1999. Cladistic analysis of Albian heteromorph ammonites. Palaeontology 42, 907-925.

DOI 10.1111/1475-4983.00102

Monks, N. 2002. Cladistic analysis of a problematic ammonite group: the Hamitidae (Cretaceous, Albian-Turonian) and proposals for new cladistic terms. Palaeontology 45, 689-707. DOI 10.1111/1475-4983.00255

ОватА, I. 1967. Lower Cretaceous ammonites from the Miyako Group Part 1 - Valdedorsella from the Miyako Group. Transactions and Proceedings of the Palaeontological Society of Japan, New series 66, 63-72.

ОватА, I. 1969. Lower Cretaceous ammonites from the Miyako Group Part 3 - Some Douvilleiceratids from the Miyako Group. Transactions and Proceedings of the Palaeontological Society of Japan, New series 76, 165-176.

ОватA, I. 1973. Lower Cretaceous ammonites from the Miyako Group Part 4 - Pseudoleymeriella from the Miyako Group. Science Reports of the Tohoku University, $2^{\text {nd }}$ series (Geology), Special Volume (Hatai Memorial Volume) 6, 309-314.

ОватA, I. \& FutAKAмi, M. 1992. Some selected ammonites from the Aptian and Albian Miyako Group, Japan. Bulletin of the National Science Museum, Series C (Geology and Paleontology) 18, 79-99.

Orbigny, A. D' 1840-1842. Paléontologie Française, Terrains Crétacés. 1. Céphalopodes. 662 pp. Masson, Paris.

Pictet, F.J. \& CAmpiche, G. 1861-1864. Description des Fossiles du Terrain crétacé des environs de Sainte-Croix, Pt. 2, 1-752. In Pictet, F.J. (ed.) Matériaux pour la Paléontologie Suisse. H. Georg, Genève.

RenZ, O. 1968. Die Ammonoidea im Stratotyp des Vraconnien bei Sainte-Croix (Kanton Waadt). Schweizerische Paläontologische Abhandlungen 87, 1-95.

Rodda, P.U. \& Murphy, M.A. 1992. Two occurrences of the genus Pictetia (early Cretaceous, Albian, Ammonoidea) in California. Journal of Paleontology 66, 435-439.

SANO, S. 1991. Discovery of a coral-rudist buildup in the Miyako Group, northeast Japan. Transactions and Proceedings of Palaeontological Society of Japan 162, 794-800.

SCHINDEWOLF, O.H. 1961-1968. Studien zur Stammesgeschichte der Ammoniten; Lieferung 1-7. Abhandlungen der Mathematisch-Naturwissenschaftlichen Klasse 1960(10)-1968(3), 1-901.

SinZow, I.F. 1905. O nekotoryh razvernutyh formah ammonitid iz verhnego neokoma Rossii [On some uncoiled ammonites from 
Upper Neocomian of Russia]. Materialy dlya geologii RossiiMaterialien zur Geologie Russlands 22, 291-332.

Spath, L.F. 1923. A monograph of the Ammonoidea of the Gault. Part 1. Palaeontographical Society Monographs 353, 1-72.

Szives, O., Csontos, L., Bujtor, L. \& Fözy, I. 2007. AptianCampanian ammonites of Hungary. Geologica Hungarica, Series Palaeontologica 57, 1-187.

SzIVEs, O. \& MonKs, N. 2002. Heteromorph ammonites from the Tata limestone formation (Aptian-Lower Albian), Hungary. Palaeontology 45, 1137-1149. DOI 10.1111/1475-4983.00279

TANAKA, K. 1978. Fossil assemblages of Miyako Group. Geological News (Geological Survey of Japan) 291, 32-48. [in Japanese]

Toshimitsu, S. \& Hirano, H. 2000. Database of the Cretaceous ammonoids in Japan - stratigraphic distribution and bibliography. Bulletin of the Geological Survey of Japan 51, 559-613.

WedEKIND, R. 1916. Über Lobus, Suturallobus und Inzision. Centralblatt für Mineralogie, Geologie und Paläontologie 8, 185-195.

Wiedmann, J. 1966. Stammesgeschichte und System der posttriadischen Ammonoideen - Ein Überblick (2. Teil). Neues Jahrbuch für Geologie und Paläontologie, Abhandlungen 127, 13-81.

Wright, C.W., Callomon, J.H. \& Howarth, M.K. 1996. Part L: Mollusca 4, revised. Volume 4: Cretaceous Ammonoidea. In Moore, R.C. (ed.) Treatise on Invertebrate Paleontology. 362 pp. The Geological Society of America \& The University of Kansas Press, Boulder \& Lawrence. 